\title{
Role of $T$ cells in granuloma formation induced by Rhodococcus aurantiacus is independent of their interferon-gamma production
}

\author{
YIMIN, MASASHI KOHANAWA, YUICHIRO SATO and TOMONORI MINAGAWA \\ Department of Microbiology, School of Medicine, Hokkaido University, Kita 15, Nishi 7, Kita-ku, Sapporo, \\ Japan
}

\begin{abstract}
Intravenous injection of Rhodococcus aurantiacus into mice causes granulomatous inflammation dependent on endogenous interferon- $\gamma$ (IFN- $\gamma$ ). This study investigated the mechanism of granuloma formation with an adoptive transfer system in IFN- $\gamma$ knockout $\left(\right.$ IFN- $\gamma^{-/-}$) mice. IFN $-\gamma^{-/-}$mice infected with $R$. aurantiacus did not develop granulomas, and high titres of endogenous interleukin-10 (IL-10) were detected in spleen extracts at 2 weeks after infection. The adoptive transfer of splenocytes from infected wild-type $\left(\mathrm{IFN}-\boldsymbol{\gamma}^{+/+}\right)$mice did not restore granuloma formation, although this treatment diminished IL-10 production in IFN- $\gamma^{-/-}$mice. Adoptive transfer of splenocytes from infected IFN- $\gamma^{-/-}$mice into infected IFN $-\gamma^{+/+}$reduced granuloma formation. These results suggest that splenocytes of IFN- $\gamma^{-/-}$mice suppress granuloma formation. On the other hand, although IFN- $\gamma$ production induced by $R$. aurantiacus infection was detected in nude mice, which are deficient in $T$ cells, granuloma formation was not induced in them. However, adoptive transfer of immune splenocytes from either IFN $-\gamma^{+/+}$mice or IFN- $\gamma^{-/-}$mice could induce granuloma formation. This means that splenocytes of IFN- $\gamma^{-/}$mice have the ability to both induce and suppress granuloma formation. Induction of granuloma is probably dependent on both $\mathrm{T}$ cells and IFN- $\gamma$ produced by non- $T$ cells. It is suggested that the role of $T$ cells in granuloma formation is not dependent on their IFN- $\gamma$ production.
\end{abstract}

\section{Introduction}

Granulomatous inflammation can be classified on the basis of cytokine profiles into type 1 characterised by interferon- $\gamma$ (IFN- $\gamma$ ) dominance and type 2 showing interleukin (IL)-4, IL-5 and IL-10 involvement [1,2]. Studies in mice with targeted knockout of cytokines help to clarify the role of cytokines in immune and inflammatory conditions. It has been reported that for type 1 granulomatous responses, IFN- $\gamma$ knockout (IFN$\gamma^{-/-}$) mice infected with Mycobacterium tuberculosis exhibit impaired resistance [3,4], and type 1 granulomatous inflammation in IFN- $\gamma^{-/-}$mice administered purified protein derivative (PPD) shifts to an exacerbated type 2 pattern [2].

Infection of wild-type (IFN- $\gamma^{+/+}$) mice with Rhodococcus aurantiacus induces the formation of nonnecrotic granuloma resembling sarcoidosis $[5,6]$,

Received 18 Dec. 2000; accepted 15 Feb. 2001.

Corresponding author: Dr Yimin. characterised by the infiltration of mononuclear phagocytes and the maturation of these cells into epithelioid cells [7-9]. A previous study reported that biphasic production of endogenous IFN- $\gamma$ appeared within $24 \mathrm{~h}$ and at 3 weeks after $R$. aurantiacus infection in mice, the former attributable to $\mathrm{NK}$ cells and the latter dependent on $\mathrm{CD}^{+} \mathrm{T}$ cells, and that granuloma formation is regulated by secretion of endogenous IFN- $\gamma[7,8,10]$. Therefore, granulomatous inflammation in $R$. aurantiacus infection is classified as type 1 . It is not clear whether IFN- $\gamma$ produced by both NK cells and T cells is important. To clarify the different roles of IFN- $\gamma$ produced by NK cells and T cells on granuloma formation, an adoptive transfer experiment was performed in IFN- $\gamma^{-/-}$mice.

\section{Materials and methods}

Animals and infection

C57BL/6 and BALB/c IFN- $\gamma^{-/-}$mice have been described previously [11]. Female C57BL/6 IFN- $\gamma^{-/-}$ mice, C57BL/6 IFN- $\gamma^{+/+}$mice, BALB/c nude mice, 
$\mathrm{BALB} / \mathrm{c} \mathrm{IFN}-\gamma^{-/-}$mice and BALB/c IFN- $\gamma^{+/+}$mice, aged $6-8$ weeks, were used. IFN- $\gamma^{-/-}$mice were phenotypically confirmed by PCR and fertility analysis [11]. IFN- $\gamma^{+/+}$mice were purchased from SLC (Hamamatsu, Shizuoka, Japan).

Mice were infected intravenously with $10^{8} \mathrm{cfu}$ of viable R. aurantiacus (strain 80005) suspended in $0.2 \mathrm{ml}$ of phosphate-buffered saline (PBS).

\section{Determination of the number of bacteria in the organs}

The numbers of viable $R$. aurantiacus in the spleens and livers of infected mice were counted by plating serial 10-fold dilutions of organ homogenates in RPMI 1640 medium (Gibco Laboratories, Grand Island, NY, USA) on Nutrient Agar (Nissui Pharmaceutical, Tokyo, Japan). Colonies that developed on the plates were counted $48 \mathrm{~h}$ later.

\section{Adoptive transfer of splenocytes}

Spleens of mice killed at 1 week post infection (p.i.) were disrupted by gentle teasing and repeated suction and expulsion through a 1-ml syringe in PBS. The single cells were resuspended in ammonium chloride $0.83 \%$ solution containing Tris buffer $10 \% \mathrm{v} / \mathrm{v}(\mathrm{pH}$ 7.65) to lyse erythrocytes, then were washed three times in RPMI 1640 medium. Cell viability was determined by the trypan blue exclusion test. Then $10^{8}$ splenocytes in $0.5 \mathrm{ml}$ of RPMI were injected intravenously into mice that had been infected with $R$. aurantiacus 1 day earlier.

\section{Preparation of organ extracts for cytokine assays}

The spleen homogenates for cytokine assays were prepared as follows. The spleens were removed aseptically from the mice and suspended in RPMI 1640 medium containing CHAPS (Wako Pure Chemical, Kyoto, Japan) $1 \% \mathrm{w} / \mathrm{v}$ and homogenates $(10 \% \mathrm{w} / \mathrm{v})$ were prepared with a Dounce grinder. The homogenates were clarified by centrifugation at $2000 \mathrm{~g}$ for $20 \mathrm{~min}$. The organ extracts were stored at $-70^{\circ} \mathrm{C}$ until cytokine assay.

Cytokine concentrations in supernates were measured in triplicate by two sandwich ELISAs. To measure IFN- $\gamma$, plates were coated with a monoclonal antibody (MAb) produced by hybridoma R4-6A2 and incubated with supernates of organ extracts. IFN- $\gamma$ was detected with polyclonal rabbit anti-IFN- $\gamma$ followed by biotinylated goat anti-rabbit IgG, streptavidin-horseradish peroxidase. IL-10 was captured with a rat anti-mouse IL-10 MAb (JES5-2A5; PharMingen) and detected with a biotinylated rat anti-mouse IL-10 MAb (SXC-1; PharMingen). The sensitivities of the ELISAs were $0.1 \mathrm{U} / \mathrm{ml}$ for IFN- $\gamma$ and $500 \mathrm{pg} / \mathrm{ml}$ for IL-10.

\section{Histological studies}

Granulomas were measured from a separate set of formalin-inflated livers that were paraffin-embedded, sectioned, then stained with haematoxylin and eosin. In each experiment, the sections were made from three-tosix pieces of each organ. The mean granuloma area was measured from the number of granulomas in all fields of each section.

\section{Statistical analysis}

Friedman's test was used to compare control with experimental groups; $\mathrm{p}<0.05$ indicated significance.

\section{Results}

\section{$R$. aurantiacus-induced granuloma formation}

A histological technique was used to investigate granuloma formation in the livers of IFN- $\gamma^{-/-}$mice and IFN- $\gamma^{+/+}$mice inoculated with $R$. aurantiacus. In the control group, granulomas in the livers of C57BL/6 and $\mathrm{BALB} / \mathrm{c}$ IFN $-\gamma^{+/+}$mice were composed primarily of mononuclear cells and lymphocytes at 1 week p.i. Nonnecrotic and epithelioid granulomas grew to maximum size at 2 weeks p.i. (C57BL/6 mice, $34 \mathrm{SD}$ $0.05 \%$; BALB/c mice, $38 \mathrm{SD} 0.05 \%$ ). Thereafter, the number of granulomas decreased and at 4 or 5 weeks p.i. the granulomas had regressed completely. In the livers of the two strains of IFN- $\gamma^{-/-}$mice, clusters of mononuclear cells and lymphocytes appeared, but no granuloma developed (Figs. 1 and 2).

Next, the effects of adoptive transfer of splenocytes from IFN- $\gamma^{-/-}$mice on granuloma formation were examined. Transfer of $10^{8}$ splenocytes from infected C57BL/6 IFN $-\gamma^{-1-}$ mice into infected C57BL/6 IFN$\gamma^{+/+}$mice reduced the area of granuloma in the tissues at 2 weeks p.i. (C57BL/6 mice, $26 \mathrm{SD} 0.05 \%$ ). In contrast, the transfer of $10^{8}$ splenocytes from infected $\mathrm{C} 57 \mathrm{BL} / 6 \mathrm{IFN}-\gamma^{+/+}$mice was not effective in inducing granuloma formation in the $\mathrm{C} 57 \mathrm{BL} / 6 \mathrm{IFN}-\gamma^{-/-}$mice (Fig. 2).

The following experiment was performed with nude mice. The intravenous injection of $10^{8} \mathrm{cfu}$ of $R$. aurantiacus into nude mice did not cause granuloma formation in the liver. However, the transfer of $10^{8}$ splenocytes from either infected BALB/c IFN- $\gamma^{+/+}$ mice or infected $\mathrm{BALB} / \mathrm{c}$ IFN- $\gamma^{-/-}$mice induced granuloma formation in the livers of the infected nude mice. The area of the granuloma induced by the latter was smaller than that induced by the former (former, 40 SD $0.05 \%$; latter, 28 SD 0.05\%) (Fig. 2).

\section{Kinetics of bacterial growth}

After C57BL/6 IFN- $\gamma^{+/+}$mice and IFN- $\gamma^{-/-}$mice were challenged with $10^{8} \mathrm{cfu}$ of $R$. aurantiacus, the 


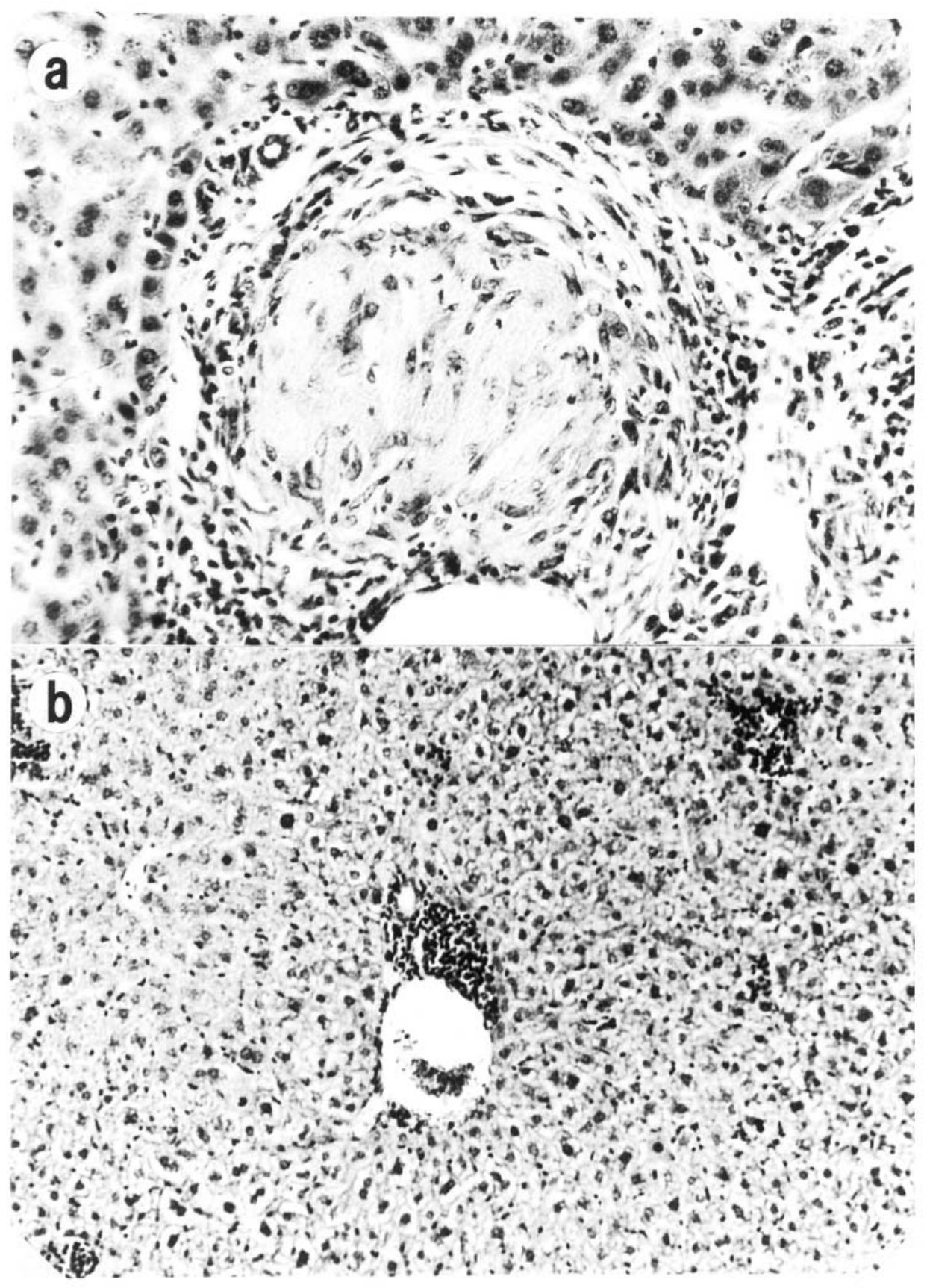

Fig. 1. Histological appearance of livers of a C57BL/6 IFN- $\gamma^{+/+}$mouse (a) and a C57BL/6 IFN- $\gamma^{-/-}$mouse (b) with $R$. aurantiacus infection at 2 weeks p.i. A granulomatous lesion is seen in the liver of the C57BL/6 IFN- $\gamma^{+/+}$mouse; clusters of mononuclear cells and lymphocytes appeared, but no granuloma developed in the tissue of the C57BL/6 IFN- $\gamma^{-/-}$mouse (magnifications: a, $400 \times ; b, 200 \times$ ).

numbers of bacteria in the livers and spleens were determined. Bacterial counts in these organs in $\mathrm{C} 57 \mathrm{BL} /$ 6 IFN $-\gamma^{+/+}$mice fell to an undetectable level by 2 weeks p.i., while those of IFN- $\gamma^{-/-}$mice were detectable at 2 weeks p.i. (Fig. 3).

\section{Endogenous cytokine production}

The study examined whether adoptive transfer of immune splenic cells from infected IFN- $\gamma^{+/+}$mice could restore IFN- $\gamma$ production and granuloma forma- tion in IFN- $\gamma^{-/-}$mice. The titres of IFN- $\gamma$ in the extracts of the spleens from either C57BL/6 IFN- $\gamma^{-/-}$ mice or $\mathrm{C} 57 \mathrm{BL} / 6 \mathrm{IFN}-\gamma^{-/-}$mice into which splenocytes of $\mathrm{C} 57 \mathrm{BL} / 6 \mathrm{IFN}-\gamma^{+/+}$mice were transferred were determined at 2 and 3 weeks p.i. Endogenous IFN- $\gamma$ was not produced in either group of mice (Fig. 4a). The titres of IFN- $\gamma$ in the extracts of spleens from $\mathrm{C} 57 \mathrm{BL} / 6 \mathrm{IFN}-\gamma^{+/+}$mice and from $\mathrm{C} 57 \mathrm{BL} / 6$ IFN- $\gamma^{+/+}$mice into which splenocytes of either C57BL6 IFN- $\gamma^{-/-}$mice or C57BL/6 IFN- $\gamma^{+/+}$mice were transferred were also determined until 3 weeks 


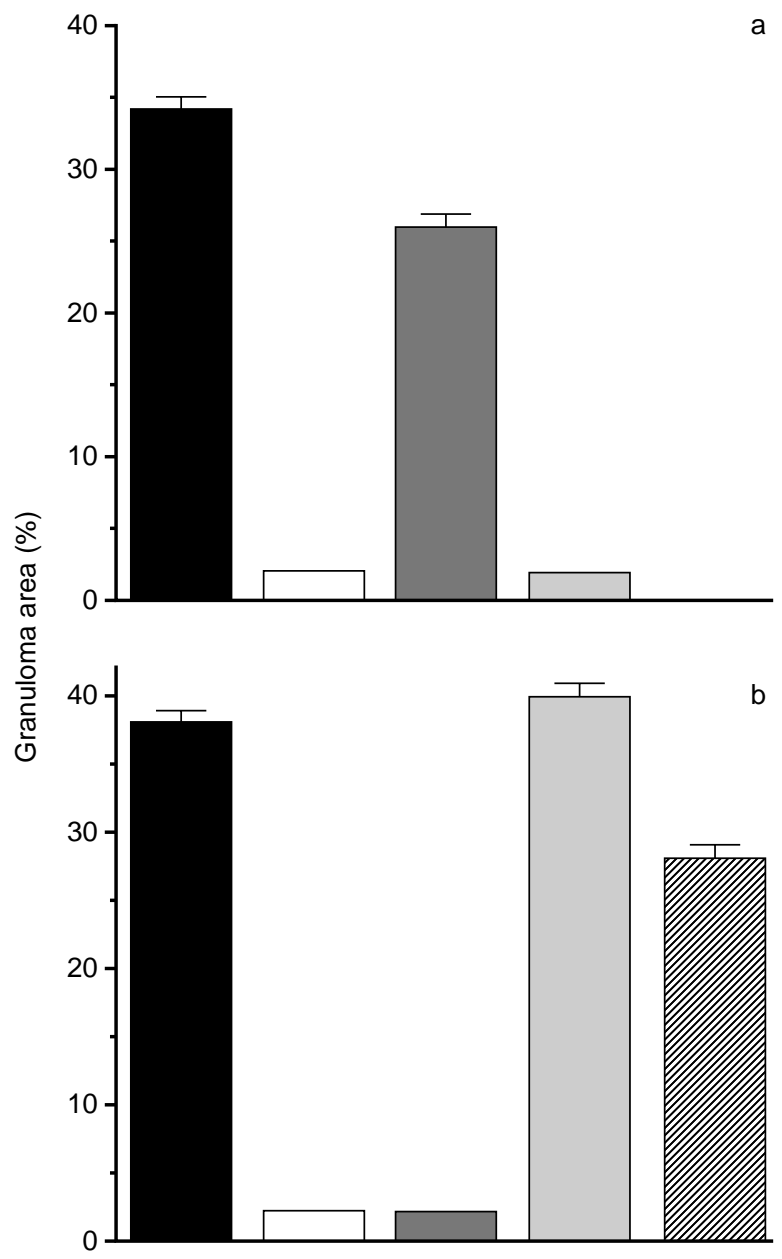

Fig. 2. Granuloma formation in the livers of various groups of mice at 2 weeks p.i. The area of granulomas in a field was determined in the sections from all areas of each of the livers of the mice. (a) C57BL/6 IFN- $\gamma^{+/+}$ mice $(\square)$, C57BL/6 IFN- $\gamma^{-/-}$mice ( $\square$ ), C57BL/6 IFN$\gamma^{+/+}$mice with splenocytes transferred from $\mathrm{C} 57 \mathrm{BL} / 6$

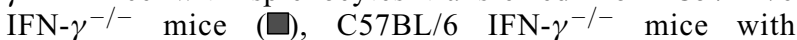
splenocytes transferred from C57BL/6 IFN- $\gamma^{+/+}$mice

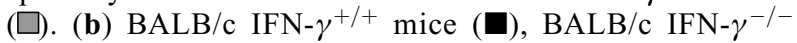
mice $(\square)$, BALB/c nude mice ( $\square$ ), BALB/c nude mice with splenocytes transferred from $\mathrm{BALB} / \mathrm{c}$ IFN- $\gamma^{+/+}$ mice ( $\square$ ), BALB/c nude mice with splenocytes transferred from BALB/c IFN- $\gamma^{-/-}$mice $(\nabla)$.

p.i. There was no significant difference in IFN- $\gamma$ production among the various groups and the peak of IFN- $\gamma$ production was seen at 2 weeks p.i. (Fig. 4b).

IFN- $\gamma$ was detected quantitatively in the extracts of spleens from infected nude mice into which splenocytes of BALB/c IFN- $\gamma^{+/+}$mice and BALB/c IFN$\gamma^{-/-}$mice, respectively, were transferred and from control nude mice by ELISA at 2 weeks p.i. IFN- $\gamma$ was detected in the spleens of the infected nude mice, and the titres of IFN- $\gamma$ from the infected nude mice that received splenocytes of BALB/c IFN- $\gamma^{+/+}$and BALB/ c IFN- $\gamma^{-/-}$mice were twice as high as those of the control group (Fig. 5).

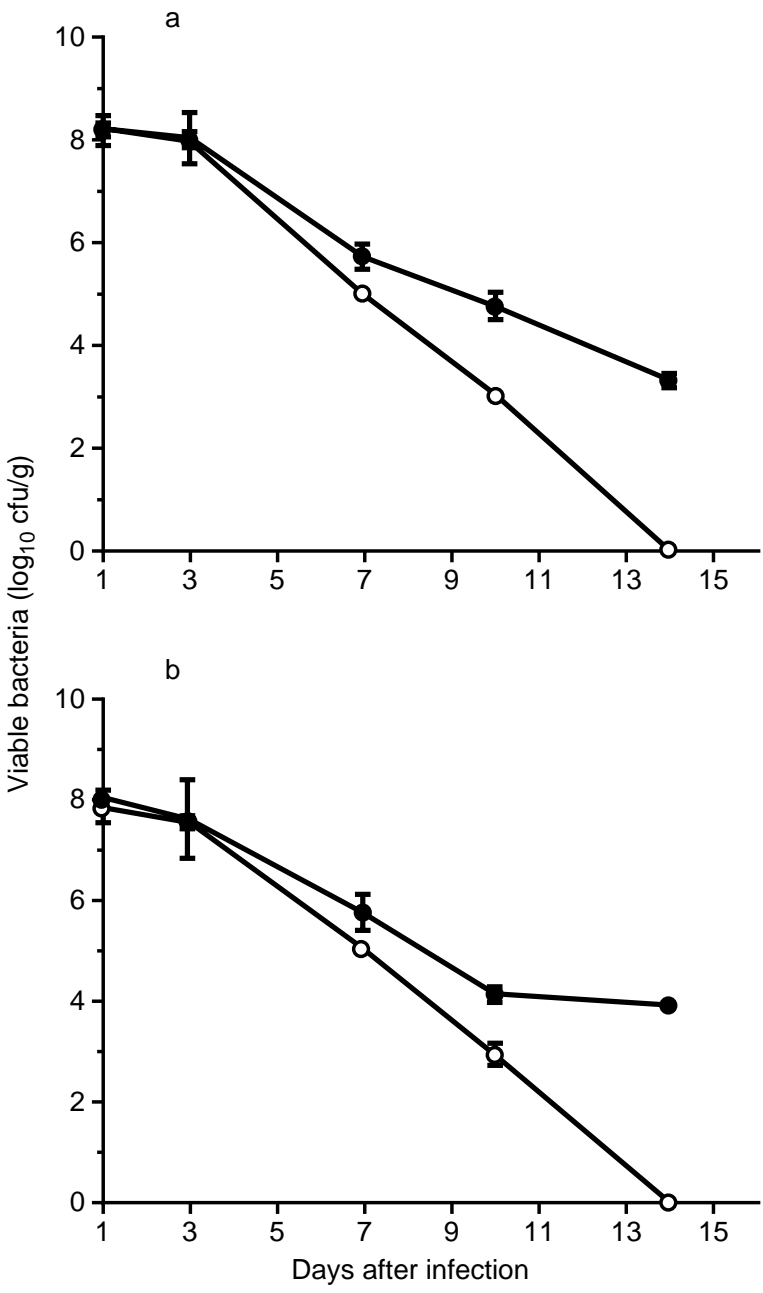

Fig. 3. Kinetics of bacterial number $\left(\log _{10} \mathrm{cfu}\right)$ in the livers and spleens of $R$. aurantiacus-infected $\mathrm{C} 57 \mathrm{BL} / 6$ IFN- $\gamma^{+/+}$mice $(O)$ and $\mathrm{C} 57 \mathrm{BL} / 6 \mathrm{IFN}-\gamma^{-/-}$mice $(\boldsymbol{O})$. Each point represents the mean and SD for 10 mice.

Furthermore, the spleen extracts obtained from the $R$. aurantiacus-infected mice were used for detection of IL-10 by ELISA. In the C57BL/ 6 IFN- $\gamma^{-/-}$mice, the level of endogenous IL-10 reached a peak at 2 weeks p.i. Adoptive transfer of splenocytes from C57BL/6 IFN- $\gamma^{+/+}$mice impeded IL-10 secretion in C57BL/6 IFN- $\gamma^{-/-}$mice (Fig. 6a). In the infected IFN $-\gamma^{+/+}$ mice and those that received spleen cells from infected IFN- $\gamma^{+/+}$mice, endogenous IL-10 was low at 2 weeks p.i. However, adoptive transfer of splenocytes from C57BL $/ 6$ IFN- $\gamma^{-/-}$mice into IFN- $\gamma^{+/+}$mice caused the elevation of IL-10 (Fig. 6b).

\section{Discussion}

It is recognised that NK cells and T cells produce IFN$\gamma$ [12-14]. A previous study demonstrated that biphasic IFN- $\gamma$ production, primarily by NK cells and secondarily by $\mathrm{T}$ cells, might contribute to granuloma formation in $R$. aurantiacus-infected mice [8]. IFN- $\gamma$ is also secreted by $\mathrm{NK}$ cells and $\mathrm{T}$ cells in Listeria 


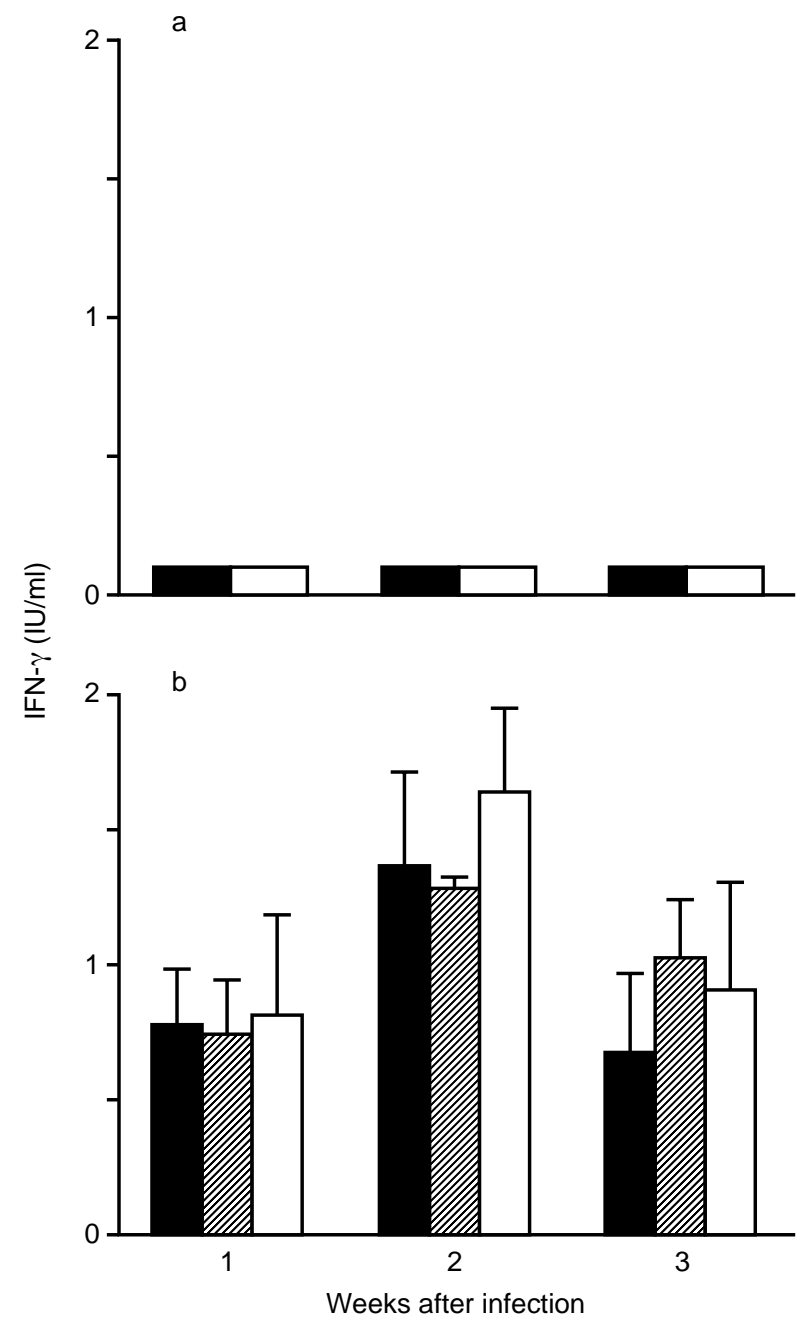

Fig. 4. Effects of adoptive transfer of splenocytes on endogenous IFN $-\gamma$ production. (a) in the spleen extracts, as in the IFN- $\gamma^{-1-}$ mice infected only (ם), IFN- $\gamma$ production could not be observed in the IFN- $\gamma^{-/-}$mice with splenocytes transferred from IFN- $\gamma^{+/+}$mice $(\square)$. (b) There was no difference in endogenous IFN- $\gamma$ production between infected-only IFN- $\gamma^{+/+}$mice (ם), and IFN $-\gamma^{+/+}$mice with splenocytes transferred from either IFN- $\gamma^{+/+}$mice $(\varangle)$ or IFN- $\gamma^{-/-}$mice $(\square)$ at $1-3$ weeks p.i. Data are the means and SDs of multiple determinations from each of three separate experiments.

monocytogenes and Salmonella enterica serotype Typhimurium infection [15-18]. It is not clear whether the role of IFN- $\gamma$ produced by $\mathrm{T}$ cells is different from that produced by non-T cells. Although IFN- $\gamma$-producing cells existed in IFN- $\gamma^{-/-}$mice that received transfer from infected IFN- $\gamma^{+/+}$mice, IFN- $\gamma$ production and granuloma formation were not restored (Fig. 2 and Fig. 4a). This indicated that IFN- $\gamma$ produced by $\mathrm{T}$ cells was not important in inducing granuloma. On the other hand, granuloma formation was induced in T-celldeficient nude mice that received splenocytes from IFN $-\gamma^{+/+}$or IFN- $\gamma^{-/-}$mice (Figs. 2 and 5). This suggested that $\mathrm{T}$ cells were important in inducing granuloma via an IFN- $\gamma$-independent mechanism. In nude mice, IFN- $\gamma$-producing cells like NK cells exist. However, IFN- $\gamma^{-/-}$mice into which splenocytes from

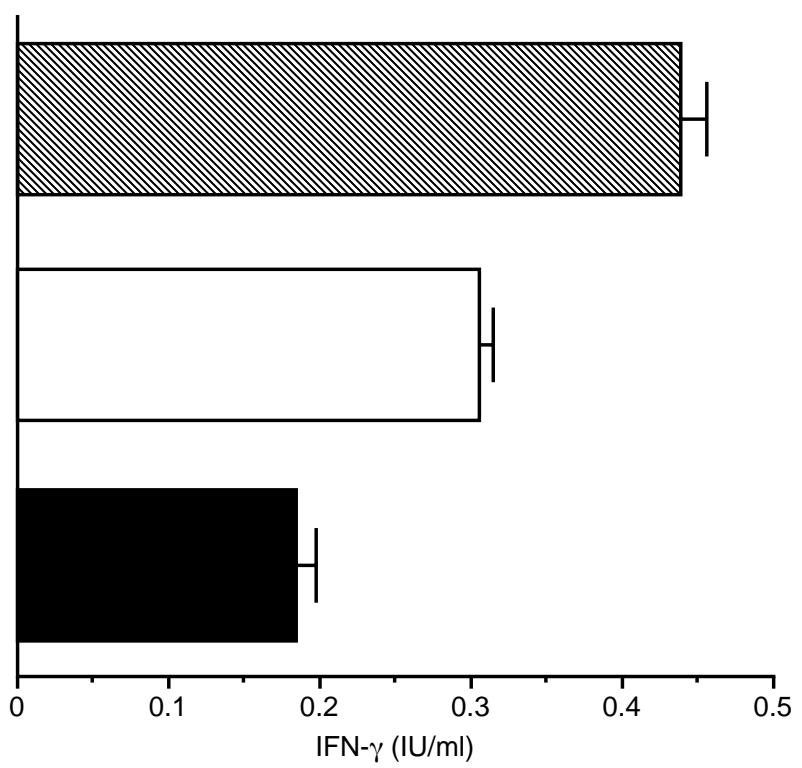

Fig. 5. Endogenous IFN- $\gamma$ production from splenocytes of infected-only BALB/c nude mice ( $\mathbf{\square}$ ), and $\mathrm{BALB} / \mathrm{c}$ nude mice with splenocytes transferred from either BALB/c IFN- $\gamma^{+/+}$mice $(\triangle)$ or BALB/c IFN- $\gamma^{-/-}$mice $(\square)$ at 2 weeks p.i. Data are the means and SDs of multiple determinations from each of three separate experiments.

IFN $-\gamma^{+/+}$mice were transferred were deficient in NK cells producing IFN- $\gamma$ because the number of NK cells in the splenocytes was smaller than that of $\mathrm{T}$ cells. Therefore, IFN- $\gamma$ produced by non-T cells, probably in the early phase of the infection, is crucial in inducing granuloma. It is reported that IFN- $\gamma$ is important in inducing granuloma in other infectious diseases [19]. However, it is not clear that IFN- $\gamma$ directly induces granuloma formation. We speculate that IFN- $\gamma$ produced by non-T cells in the early phase of the infection stimulates $\mathrm{T}$ cells, and that they produce some factors for inducing granuloma formation directly. For example, it is reported that nitric oxide directly induces granuloma formation [20]. It is possible that some factor(s) such as nitric oxide is directly important in inducing granuloma in $R$. aurantiacus infection [20].

Granulomas were not induced in $\mathrm{IFN}-\gamma^{-/-}$mice infected with $R$. aurantiacus because of the lack of non-T cells producing IFN- $\gamma$. However, it is possible that there is another mechanism that suppresses granuloma formation. It is reported that $\mathrm{Th} 2$ cytokines such as IL-4 and IL-10 are antagonistic for the activities of Th1 cytokines and decrease the size of granulomas [10]. This preferential expression of Th1 cytokines versus Th2 cytokines may be driven by various mechanisms. Transfer of splenocytes from IFN$\gamma^{+/+}$mice into IFN- $\gamma^{-/-}$mice was not effective in restoring granuloma formation (Fig. 2). We speculate that splenocytes of IFN- $\gamma^{-/-}$mice have a suppressive function against granuloma formation. It was thought that the number of Th2-type cells increased in splenocytes of IFN- $\gamma^{-/-}$mice, and that these cells inhibited granuloma formation and Th1 cytokine 

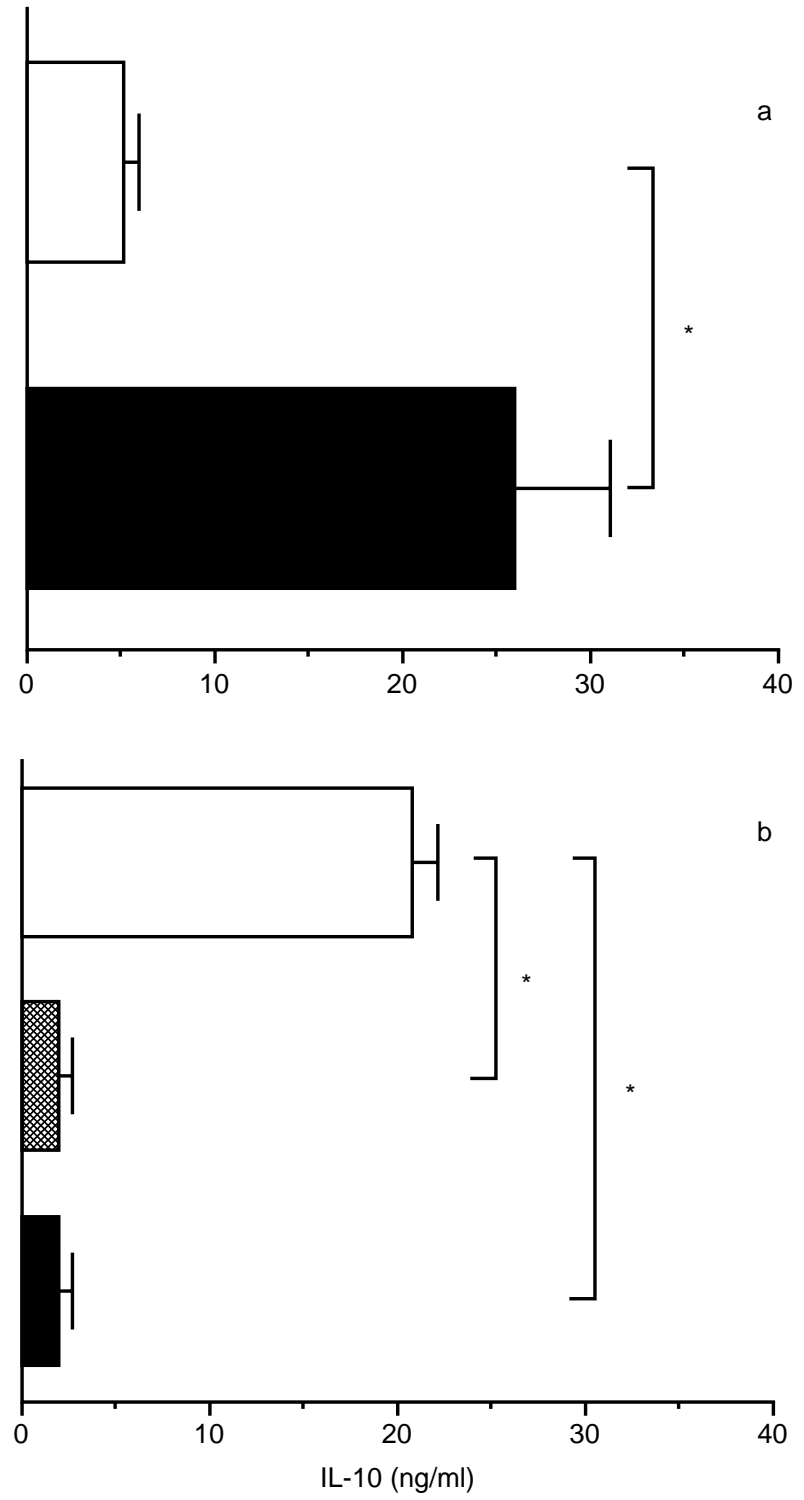

Fig. 6. Effects of adoptive transfer of C57BL/6 mouse splenocytes on endogenous IL-10 production at 2 weeks p.i. (a) IL-10 production in spleens of the infected-only IFN- $\gamma^{-/-}$mice (ם) and IFN- $\gamma^{-/-}$mice with splenocytes transferred from IFN- $\gamma^{+/+}$mice $(\square)$. (b) IL-10 production in the spleens of infected-only IFN $-\gamma^{+/+}$mice $(\mathbf{\square})$, and IFN $-\gamma^{+/+}$mice with splenocytes transferred from either IFN- $\gamma^{+/+}$mice $(\square)$ or IFN- $\gamma^{-/-}$mice $(\square)$. $* \mathrm{p}<0.01$.

production by $\mathrm{T}$ cells of IFN- $\gamma^{+/+}$mice. It has been reported that $\mathrm{Th} 2$ cytokines in $\mathrm{IFN}-\gamma^{-/-}$mice are increased by stimulation with mycobacterial antigens compared with IFN $-\gamma^{+/+}$mice [2]. In the present study, increases of IL-4 were not observed in the IFN $-\gamma^{-/-}$mice (unpublished data). However, the titre of IL-10 in the extracts of the spleen at 2 weeks after infection was greater than in IFN- $\gamma^{+/+}$mice (Fig. 6a). Furthermore, the adoptive transfer of splenocytes of IFN $-\gamma^{-/-}$mice to IFN- $\gamma^{+/+}$mice caused the elevation of IL-10 in the spleen (Fig. 6b) and the number of granulomas was diminished in the liver (Fig. 2). IL-10 is a cytokine mainly derived from macrophages, and it has been reported that neutralisation of endogenous IL10 restores in-vitro production of IFN- $\gamma$ by spleen cells and enhances host resistance against infection with $M$. avium $[21,22]$. The present study indicated that mice infected with $R$. aurantiacus were able to produce IL10 , but its production was normally inhibited by IFN- $\gamma$ during the granuloma formation phase in $\mathrm{IFN}-\gamma^{+/+}$ mice.

\section{References}

1. Chensue SW, Warmington KS, Ruth JH, Lincoln P, Kunkel SL. Cytokine function during mycobacterial and schistosomal antigen-induced pulmonary granuloma formation. Local and regional participation of IFN- $\gamma$, IL-10 and TNF. $J$ Immunol 1995; 154: 5969-5976.

2. Chensue SW, Warmington K, Ruth JH, Lukacs N, Kunkel SL. Mycobacterial and schistosomal antigen-elicited granuloma formation in IFN- $\gamma$ and IL-4 knockout mice. Analysis of local and regional cytokine and chemokine networks. J Immunol 1997; 159: 3565-3573.

3. Cooper AM, Dalton DK, Stewart TA, Griffin JP, Russell DG, Orme IM. Disseminated tuberculosis in interferon $\gamma$ genedisrupted mice. J Exp Med 1993; 178: 2243-2247.

4. Flynn JL, Chan J, Triebold KJ, Dalton DK, Stewart TA, Bloom BR. An essential role for interferon $\gamma$ in resistance to Mycobacterium tuberculosis infection. J Exp Med 1993; 178: 2249-2254.

5. Sugiyama Y. Macrophage activation in sarcoidosis. Clin Immunol 1998; 30: 199-206.

6. Asano M, Minagawa T, Ohmichi M, Hiraga Y. Detection of endogenous cytokines in sera or in lymph nodes obtained from patients with sarcoidosis. Clin Exp Immunol 1991; 84: 92-96.

7. Asano M, Nakane A, Minagawa T. Endogenous gamma interferon is essential in granuloma formation induced by glycolipid-containing mycolic acid in mice. Infect Immun 1993; 61: 2872-2878.

8. Asano M, Nakane A, Kohanawa M, Minagawa T. Sequential involvement of NK cells and $\mathrm{CD}^{+} \mathrm{T}$ cells in granuloma formation of Rhodococcus aurantiacus-infected mice. Microbiol Immunol 1995; 39: 499-507.

9. Kaneda K, Sumi Y, Kurano Y, Kato Y, Yano I. Granuloma formation and hemopoiesis induced by C36-48-mycolic acidcontaining glycolipids from Nocardia rubra. Infect Immun 1986; 54: 869-875.

10. Asano M, Kohanawa M, Minagawa T, Nakane A. Reciprocal action of interferon- $\gamma$ and interleukin-4 promotes granulomatous inflammation induced by Rhodococcus aurantiacus in mice. Immunology 1996; 88: 394-399.

11. Tagawa Y, Sekikawa K, Iwakura Y. Suppression of concanavalin A-induced hepatitis in IFN- $\gamma^{-/-}$mice, but not in TNF$\alpha^{-/-}$mice. Role for IFN- $\gamma$ in activating apoptosis of hepatocytes. J Immunol 1997; 159: 1418-1428.

12. Dunn PL, North RJ. Early gamma interferon production by natural killer cells is important in defense against murine listeriosis. Infect Immun 1991; 59: 2892-2900.

13. Squires KE, Schreiber RD, McElrath MJ, Rubin BY, Anderson SL, Murray HW. Experimental visceral leishmaniasis: role of endogenous IFN- $\gamma$ in host defense and tissue granulomatous response. J Immunol 1989; 143: 4244-4249.

14. Bogen SA, Fogelman I, Abbas AK. Analysis of IL-2, IL-4, and IFN- $\gamma$ producing cells in situ during immune responses to protein antigens. J Immunol 1993; 150: 4197-4205.

15. Sacco RE, Jensen RJ, Thoen CO et al. Cytokine secretion and adhesion molecule expression by granuloma $\mathrm{T}$ lymphocytes in Mycobacterium avium infection. Am J Pathol 1996; 148: 1935-1948.

16. Nakane A, Numata A, Chen Y, Minagawa T. Endogenous gamma interferon-independent host resistance against Listeria monocytogenes infection in $\mathrm{CD}^{+}{ }^{+} \mathrm{T}$ cell- and asialo $\mathrm{GM}^{+}$ cell-depleted mice. Infect Immun 1991; 59: 3439-3445.

17. Nakane A, Numata A, Asano M, Kohanawa M, Chen Y, Minagawa T. Evidence that endogenous gamma interferon is produced early in Listeria monocytogenes infection. Infect Immun 1990; 58: 2386-2388. 
18. Ramarathinam L, Niesel DW, Klimpel GR. Ity influences the production of IFN- $\gamma$ by murine splenocytes stimulated in vitro with Salmonella typhimurium. $J$ Immunol 1993; 150: 3965-3972.

19. Jouanguy E, Döffinger R, Dupuis S, Pallier A, Altare F, Casanova J-L. IL-12 and IFN-gamma in host defense against mycobacteria and salmonella in mice and men. Curr Opin Immunol 1999; 11: 346-351.

20. Ehlers S, Kutsch S, Benini J et al. $\mathrm{NOS}_{2}$-derived nitric oxide regulates the size, quantity and quality of granuloma formation in Mycobacterium avium-infected mice without affecting bacterial loads. Immunology 1999; 98: 313-323.

21. Bermudez LE, Champsi J. Infection with Mycobacterium avium induces production of interleukin-10 (IL-10), and administration of anti-IL-10 antibody is associated with enhanced resistance to infection in mice. Infect Immun 1993; 61: 3093-3097.

22. Denis M, Ghadirian E. IL-10 neutralization augments mouse resistance to systemic Mycobacterium avium infections. J Immunol 1993; 151: 5425-5430. 